\title{
Pengembangan E-Modul Berbasis Aplikasi Android pada Materi Perbandingan Berbalik Nilai
}

\author{
Ilham Kartiko ${ }^{1}$, Helti Lygia Mampouw ${ }^{2}$ \\ ${ }_{1,2}$ Program Studi Pendidikan Matematika, Fakultas Keguruan dan Ilmu Pendidikan, Universitas Kristen Satya Wacana, \\ Jl. Diponegoro 52-60 Kota Salatiga, Indonesia \\ 202017028@student.uksw.edu
}

\begin{abstract}
The era of the Industrial Revolution 4.0 encourages the use of information and communication technology in education, such as e-modules. The purpose of this study was the development of the PSBB e-module media containing material on the comparison of turning points for junior high school students. This study uses the ADDIE development model, namely analysis, design, development, implementation and evaluation. The PSBB e-module is packaged for interactive learning and is equipped with a LKPD which functions as a control tool for student learning progress as well as an evaluation tool. E-modules that have been confirmed as valid are implemented for 35 grade VII students of SMP Negeri 6 Salatiga. The trial results showed that the PSBB e-module was responded well by students and had a practicality value of $86 \%$. The PSBB e-module which is supported by the LKPD is very effective in helping students achieve $85 \%$ of completing learning material comparison against grades. These results provide information that the PSBB e-module can be widely used by junior high school students.
\end{abstract}

Keywords: E-Module Development, Value Reverse Comparison, Mathematics

\begin{abstract}
Abstrak
Era Revolusi Industri 4.0 mendorong penggunaan teknologi informasi dan komunikasi di bidang pendidikan, salah satunya adalah e-modul. Tujuan penelitian ini adalah pengembangan media e-modul PSBB berisi materi perbandingan berbalik nilai untuk siswa SMP. Penelitian ini menggunakan model pengembangan ADDIE yang terdiri dari tahapan analisis, desain, pengembangan, implementasi dan evaluasi. E-modul PSBB dikemas untuk pembelajaran interaktif dan dilengkapi LKPD yang berfungsi sebagai alat kontrol kemajuan belajar siswa sekaligus alat evaluasi. E-modul yang telah terkonfirmasi valid diimplementasikan kepada 35 siswa kelas VII SMP Negeri 6 Salatiga. Hasil uji coba menunjukkan e-modul PSBB direspon baik oleh siswa dan memiliki nilai kepraktisan $86 \%$. E-modul PSBB yang didukung oleh LKPD sangat efektif membantu siswa mencapai $85 \%$ tuntas belajar materi perbandingan berbalik nilai. Hasil ini memberikan informasi bahwa e-modul PSBB dapat digunakan secara luas oleh siswa SMP.
\end{abstract}

Kata kunci: Pengembangan E-Modul, Perbandingan Berbalik Nilai, Matematika

Copyright (c) 2021 Ilham Kartiko, Helti Lygia Mampouw

$\triangle$ Corresponding author: Ilham Kartiko

Email Address: 202017028@ student.ukw.edu (Jl. Diponegoro 52-60 Kota Salatiga, Indonesia)

Received 15 Juni 2021, Accepted 22 Juni 2021, Published 24 Juni 2021

\section{PENDAHULUAN}

Perbandingan merupakan salah satu materi bilangan yang diajarkan di SD dan SMP. Mengacu pada Permendikbud Nomor 37 Tahun 2018, kompetensi siswa SD terkait materi perbandingan yakni dapat menjelaskan perbandingan dua besaran yang berbeda (kecepatan sebagai perbandingan jarak dengan waktu, debit sebagai perbandingan volume dan waktu), dan kompetensi siswa SMP siswa dapat menjelaskan rasio dua besaran (satuannya sama dan berbeda) serta dapat membedakan perbandingan senilai dan berbalik nilai dengan menggunakan tabel data, grafis, dan persamaan (Permendikbud No.37 Tahun 2018). Pencapaian kompetensi pada materi perbandingan merupakan dasar untuk pencapaian kompetensi selanjutnya baik di dalam matematika, pelajaran lain maupun kecakapan di dalam kehidupan sehari-hari.

Pencapaian kompetensi mata pelajaran matematika berdasarkan Permendikbud No. 37 tahun 2018 
Pengembangan E-Modul Berbasis Aplikasi Android pada Materi Perbandingan Berbalik Nilai, Ilham Kartiko, Helti Lygia Mampouw

didukung oleh kesiapan siswa dalam menerima materi yang berhubungan dengan perkembangan kognitif. Menurut Piaget, siswa SMP pada kisaran usia 11 sampai dengan 15 tahun berada pada tahapan operasi formal awal. Pada tahap ini siswa sudah dapat menggunakan operasi-operasi konkretnya untuk membentuk operasi yang lebih kompleks (Dahar, 2006). Dengan demikian struktur materi perbandingan untuk SMP yang sudah diatur sesuai perkembangan kognitif dapat diterima dan dipahami oleh siswa.

Kenyataannya materi perbandingan belum sepenuhnya dipahami dengan baik oleh siswa SMP. Ishana (2014) menemukan bahwa perbandingan merupakan materi yang sulit dipahami oleh siswa karena sumber belajar yang digunakan hanya berupa buku teks. Hamidah et al., (2018) di dalam penelitiannya menyatakan bahwa siswa masih kesulitan dalam memahami konsep perbandingan dan memahami arti perbandingan senilai. Tiffani (2015) menemukan bahwa siswa masih kesulitan dalam menyelesaikan permasalahan yang melibatkan konsep perbandingan senilai dan berbalik nilai, dikarenakan siswa masih kesulitan dalam membedakan keduanya. Raharjanti et al., (2016) menjelaskan dalam penelitiannya bahwa mayoritas siswa belum bisa membedakan masalah perbandingan senilai dan masalah perbandingan berbalik nilai.

Hasil belajar perbandingan senilai dan berbalik nilai yang rendah juga ditunjukkan oleh hasil-hasil ujian nasional (UN). Tabel 1 menampilkan hasil UN tahun 2019.

Tabel 1. Data Hasil UN tahun 2019 Materi Bilangan dan Perbandingan

\begin{tabular}{|c|c|c|}
\hline Tingkat & Bilangan & Perbandingan \\
\hline Kota Semarang & 51,68 & 66,26 \\
\hline Kab. Semarang & 48,88 & 59,90 \\
\hline Kota Salatiga & 60,12 & 75,35 \\
\hline Kab. Kendal & 39,61 & 47,96 \\
\hline Kab. Demak & 35,39 & 42,96 \\
\hline Kab. Grobogan & 36,05 & 43,54 \\
\hline Nasional & 38,51 & 45,24 \\
\hline Jawa Tengah & 44,30 & 54,05 \\
\hline
\end{tabular}

Sumber: https://hasilun.puspendik.kemdikbud.go.id

Tabel 1 menampilkan bahwa baik materi bilangan secara keseluruhan maupun materi perbandingan, kota Salatiga memiliki daya serap paling tinggi dibandingkan kota dan kabupaten lainnya di karesidenan Semarang, tingkat provinsi maupun tingkat nasional. Informasi hasil UN ini pula dapat dijadikan acuan tentang kesiapan belajar siswa.

Era Revolusi Industri 4.0 mendorong penggunaan teknologi informasi dan komunikasi di bidang pendidikan. Bahan-bahan ajar disiapkan dan disampaikan kepada siswa dengan lebih baik agar dapat menarik minat belajar siswa. Di sisi lain, teknologi informasi dan komunikasi telah sampai kepada siswa. Mereka mampu dengan cepat beradaptasi dengan kemajuan di bidang teknologi. Umumnya siswa dapat belajar secara mandiri menggunakan aplikasi permainan dan aplikasi media sosial pada smartphone. Berbagai informasi dapat mereka akses dari smartphone. Hal ini menjadi peluang di dalam menciptakan media-media belajar berbasis smartphone untuk siswa terutama dimasa pandemic Covid-19. 
Selama PJJ (Pembelajaran Jarak Jauh) karena Covid-19 mengakibatkan guru kurang maksimal dalam menyampaikan sebuah materi, sehingga diperlukannya sebuah media yang dapat membantu kegiatan pembelajaran. E-modul menjadi salah satu pilihan untuk desain pembelajaran berbasis digital pada perbandingan senilai dan berbalik nilai yang dapat digunakan dimasa pancemic Covid-19 maupun kegiatan pembelajaran secara tatap muka. E-modul berisi bahan ajar yang dapat dijalankan secara mandiri oleh siswa dengan memanfaatkan teknologi informasi dan komunikasi. Ula \& Fadila (2018) mengembangkan e-modul berbasis learning content development system yang valid dan praktis pada materi pola bilangan. Andika (2017) mengembangkan e-modul interaktif berbasis problem based learning yang valid dan parktis pada materi kubus dan balok. Wahyudi (2019) menggunakan e-modul berbasis android pada materi lingkaran. Hidayatulloh (2016) mengembangkan e-modul berbasis Problem Based Learning pada materi bilangan bulat. Hasil-hasil ini memperkuat posisi e-modul sebagai bahan ajar berbasis teknologi dan informasi.

Teknologi informasi dan komunikasi yang terus berkembang dan daya serap siswa masih belum sesuai harapan pada materi perbandingan senilai dan berbalik nilai mendorong dikembangkannya media pembelajaran berbasis digital. Tujuan penelitian ini adalah mengembangkan media e-modul PSBB (Perbandingan Senilai \& BerBalik nilai) berisi materi perbandingan yang valid, praktis, dan efektif sehingga dapat digunakan secara luas oleh siswa SMP.

\section{METODE}

Penelitian ini adalah penelitian pengembangan atau Research and Development (R\&D). Penelitian pengembangan merupakan metode penelitian yang digunakan untuk menghasilkan produk tertentu,dan menguji keefektifan produk tersebut (Sugiyono, 2018: 297). Penelitian ini menggunakan model pengembangan ADDIE, yang meliputi 5 tahapan yaitu analyze (analisis), design (desain), development (pengembangan), implementation (implementasi) dan evaluation (evaluasi). Gambar 1 menampilkan bagan pengembangan ADDIE.

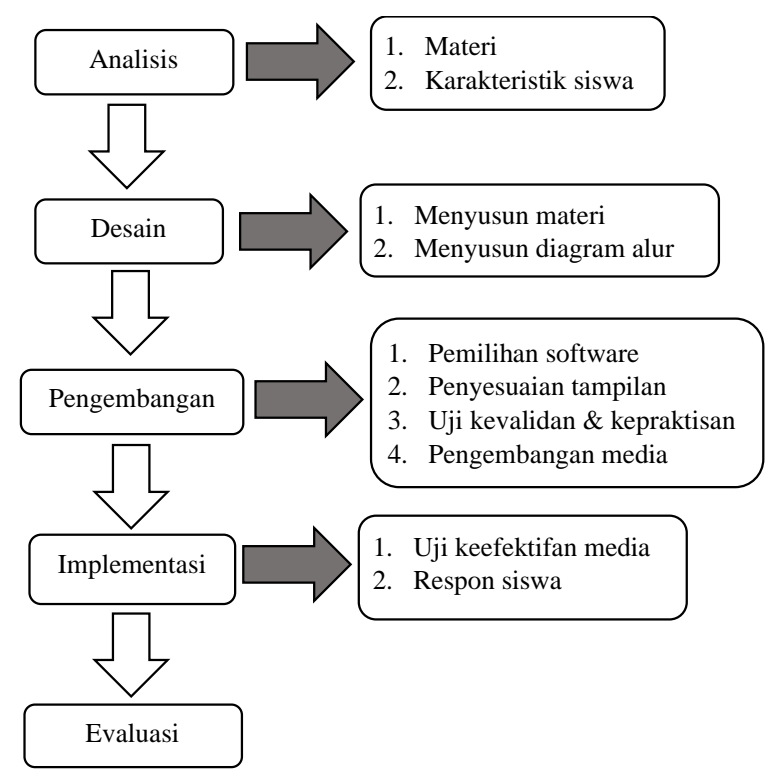

Gambar 1. Bagan Pengembangan ADDIE 
Pengembangan E-Modul Berbasis Aplikasi Android pada Materi Perbandingan Berbalik Nilai, Ilham Kartiko, Helti Lygia Mampouw

Penelitian ini menghasilkan produk berupa e-modul PSBB yang valid, praktis dan efektif ketika digunakan dalam pembelajaran. Hasil dari produk penelitian pengembangan ini diimplemetasikan pada bulan Januari sampai Maret 2021 kepada 92 siswa SMP Kelas VII. Teknik pengumpulan data penelitian ini menggunakan angket dan tes untuk menguji kevalidan, kepraktisan dan keefektifan. Analisis untuk menguji kevalidan dan kepraktisan atas dasar pengisian angket menggunakan persentase jumlah skor perolehan dari skor maksimum. Hasil persentase ini menjadi kategori penilaian dari e-modul yang dikembangkan dengan aturan yang ditampilkan pada Tabel 2 dan Tabel 3 (Aswardi et al., 2019).

Tabel 2. Kriteria Penilaian Kevalidan Media

\begin{tabular}{|c|c|}
\hline Tingkat Pencapaian (\%) & Kategori \\
\hline $90-100$ & Sangat Valid \\
\hline $80-89$ & Valid \\
\hline $65-79$ & Cukup Valid \\
\hline $55-64$ & Kurang Valid \\
\hline $0-54$ & Tidak Valid \\
\hline
\end{tabular}

Tabel 3. Kriteria Penilaian Kepraktisan Media

\begin{tabular}{|c|c|}
\hline Tingkat Pencapaian (\%) & Kategori \\
\hline $90-100$ & Sangat Praktis \\
\hline $80-89$ & Praktis \\
\hline $65-79$ & Cukup Praktis \\
\hline $55-64$ & Kurang Praktis \\
\hline $0-54$ & Tidak Praktis \\
\hline
\end{tabular}

Analisis untuk menguji keefektifan dilihat berdasarkan skor hasil lembar kerja siswa (LKS) dan lembar respons siswa. Media dinyatakan memiliki tingkat keefektifan yang baik jika minimal persentase ketuntasan belajar menggunakan media yang diperoleh termasuk dalam kategori Efektif atau persentase banyak siswa yang memperoleh nilai lebih dari KKM (nilai $\geq 76$ ) berada pada rentan $60<p \leq 80$, sedangkan pada lembar respons siswa menggunakan rumus:

$$
X=\frac{\text { skor total respons siswa }}{\text { skor maksimum respons siswa }} \times 100 \%
$$

Persentase ketuntasan siswa dikategorikan berdasarkan kriteria menurut Eko Widyoko (2016: 242) yang terdapat pada Tabel 4, dan persentase hasil penilaian respons siswa dikategorikan menurut kriteria yang terdapat pada Tabel 5 (Hidayatullah, 2016).

Tabel 4. Kriteria Keefektifan Media

\begin{tabular}{|c|c|}
\hline Persentase Ketuntasan (\%) & Kategori \\
\hline$p>80$ & Sangat Efektif \\
\hline $60<p \leq 80$ & Efektif \\
\hline $40<p \leq 60$ & Cukup Efektif \\
\hline $20<p \leq 40$ & Kurang Efektif \\
\hline$p \leq 20$ & Tidak Efektif \\
\hline
\end{tabular}

Ket: $p=$ persentase ketuntasan 
Tabel 5. Kriteria Penilaian Respon Siswa

\begin{tabular}{|c|c|}
\hline Tingkat Pencapaian (\%) & Kategori \\
\hline $82-100$ & Sangat Praktis \\
\hline $63-81$ & Praktis \\
\hline $44-62$ & Cukup Praktis \\
\hline $20-43$ & Kurang Praktis \\
\hline
\end{tabular}

\section{HASIL DAN DISKUSI}

\section{Hasil Penelitian}

Hasil dari penilitian pengembangan ini berupa e-modul yang dapat membantu siswa belajar secara mandiri dan dapat dilakukan kapanpun dan dimanapun. Penelitian pengembangan ini menggunakan model pengembangan ADDIE sebagai berikut.

\section{Tahap Analisis}

Tahap ini meliputi analisis terhadap permasalahan dan mengembangkan media sebagai solusi permasalahan tersebut. Analisis dilakukan berdasarkan materi perbandingan dan karakteristik siswa. Materi perbandingaan terdiri dari perbandingan senilai dan perbandingan berbalik nilai. Siswa pada era Revolusi Industri 4.0 sangat tertarik dengan model permainan berbasis digital. Pandemi Covid-19 telah mendorong mempercepat pemanfaatan teknologi digital di bidang pendidikan. Oleh karena itu sangat tepat untuk mengembangkan sebuah media pembelajaran yang sederhana menarik dan fleksibel serta dapat menumbuhkan motivasi belajar serta membantu peserta didik dalam memahami materi perbandingan berbalik nilai dengan mudah dalam bentuk e-modul.

\section{Tahap Desain}

Tahapan ini dimulai dengan menyusun materi dan menyusun diagram alur e-modul materi perbandingan. Diagram alur menggambarkan proses belajar siswa menggunakan e-modul. Gambar 2 menampilkan diagram alur dimaksud. Selain itu, pada tahap ini juga dilakukan pemilihan konteks yang sudah dikenal siswa dan rencana soal terkait materi perbandingan. Diagram alur pada Gambar 2 menjelaskan alur belajar perbandingan. Alur belajaar menekankan kesiapan siswa belajar materi secara bertahap. Siswa dapat melanjutkan belajar pada materi berikutnya setelah menyelesaikan soal yang disyaratkan. Penyelesaian soal dihargai dengan skor. Jika siswa belum mencapai skor yang ditentukan, maka siswa akan kembali mempelajari materi sebelumnya. Prinsip tersebut berlaku hingga materi ke-4. Pembahasan difokuskan pada mengaitkan data dan hasil analisisnya dengan permasalahan atau tujuan penelitian dan konteks teoretis yang lebih luas. Pembahasan dapat juga merupakan jawaban pertanyaan mengapa ditemukan fakta seperti pada data. Pada tahap ini pula ditentukan nama media yakni e-modul PSBB (Perbandingan Senilai \& Berbalik nilai). E-modul ini dikembangkan untuk digunakan pada smartphone berbasis operasi sistem android. 

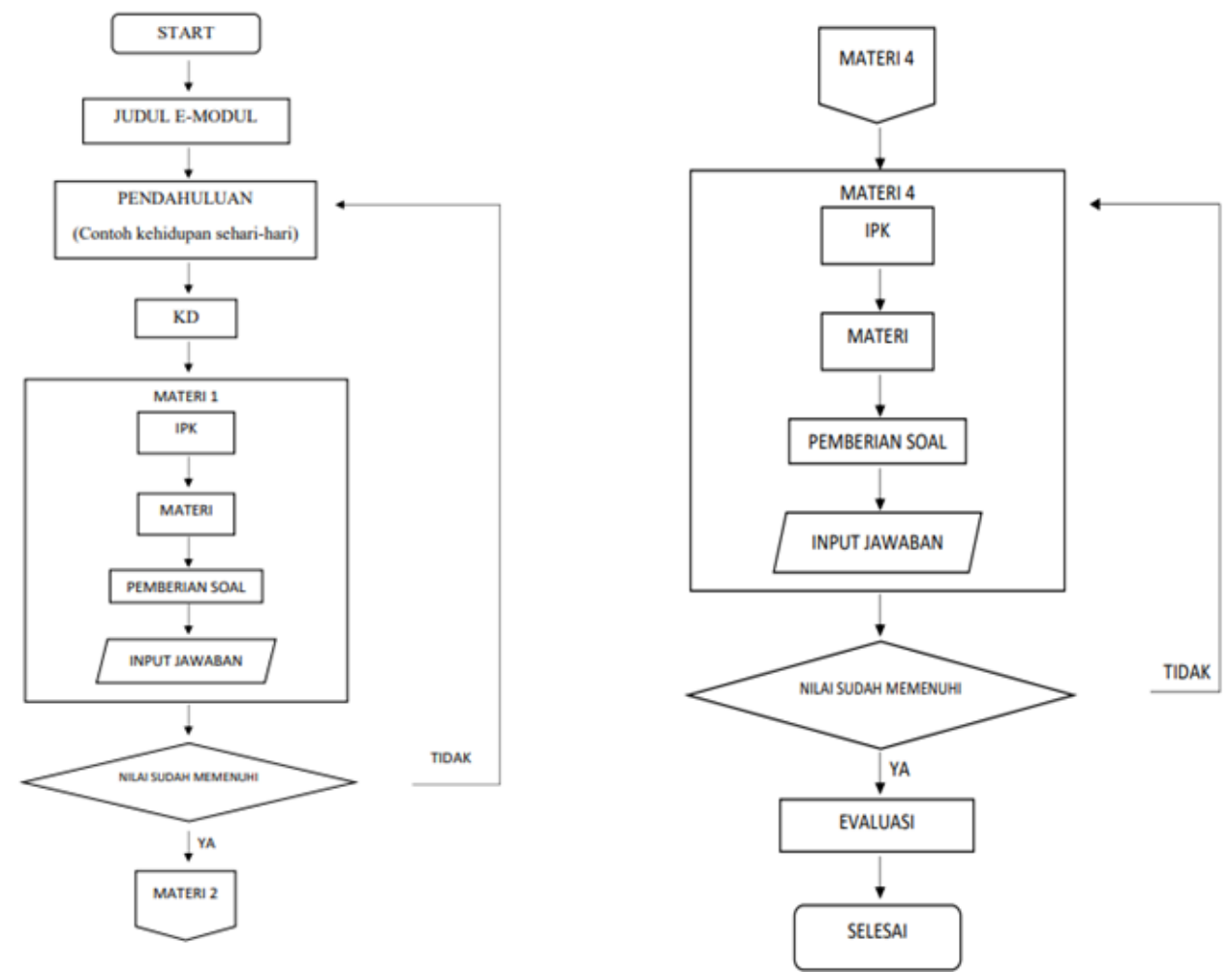

Gambar 2. Diagram E-Modul

\section{Tahap Pengembangan}

Pengembangan e-modul PSBB dilanjutkan dengan memilih software dan penggunaannya. Corel Draw dipilih untuk membuat tampilan-tampilan yang kemudian diekspor ke aplikasi Adobe Animate CC untuk membuat beberapa animasi sekaligus merubah ke bentuk file aplikasi android. Unsur-unsur yang terdapat pada e-modul PSBB yang perlu diperhatikan meliputi teks, gambar, tema, audio serta animasi telah disesuaikan dengan karakter siswa SMP agar dapat memberi suasana belajar melalui permainan. Aplikasi e-modul PSBB ini dapat dioperasikan pada smartphone berbasis android dengan spesifikasi minimal Operasi Sistem (OS) 7 Nougat.

Tampilan e-modul PSBB ini terdapat beberapa bagian didalamnya, yang meliputi halaman judul, menu yang berisi materi beserta KI \& KD, materi, contoh soal, latihan soal, dan soal evaluasi, sehingga dapat mengarahkan peserta didik belajar secara mandiri. Desain tersebut ditampilkan pada Gambar 3, Gambar 4, dan Gambar 5.

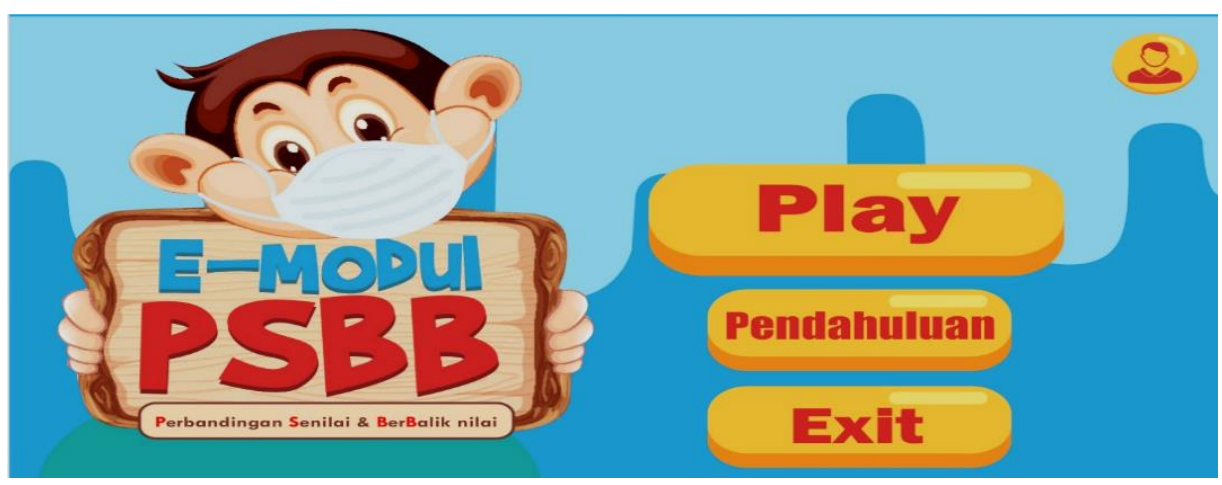

Gambar 3. Halaman Judul E-modul 


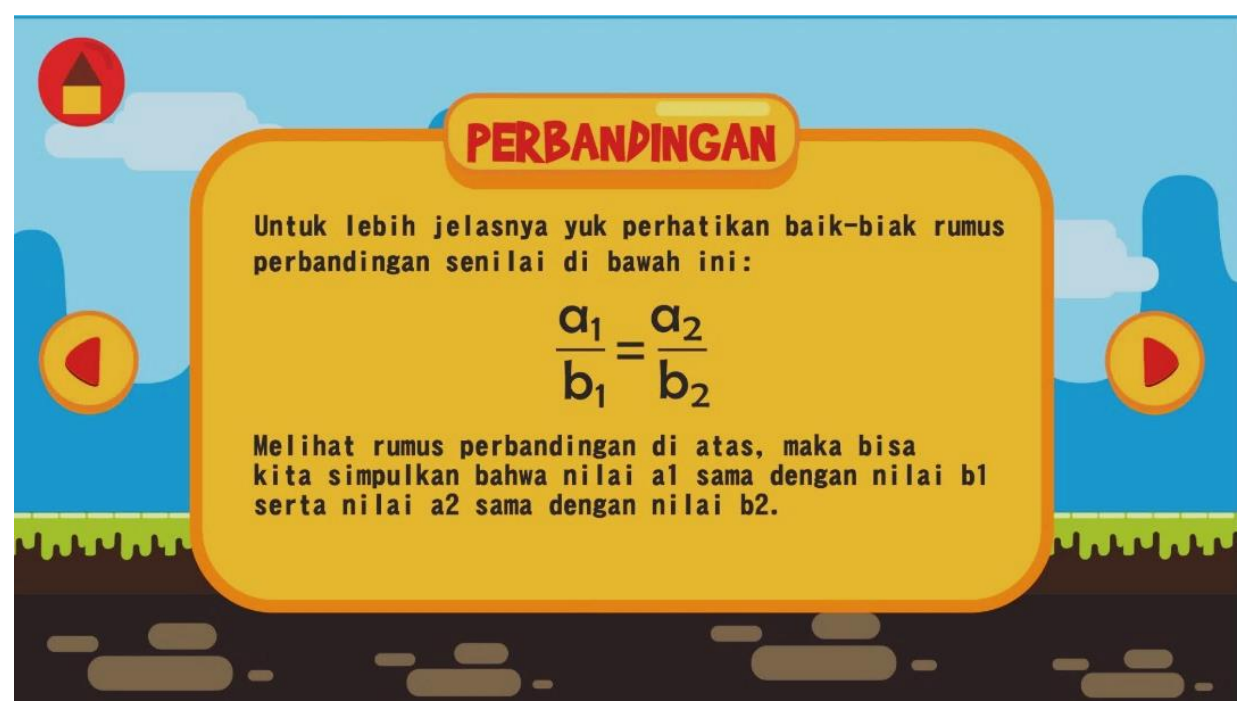

Gambar 4. Materi

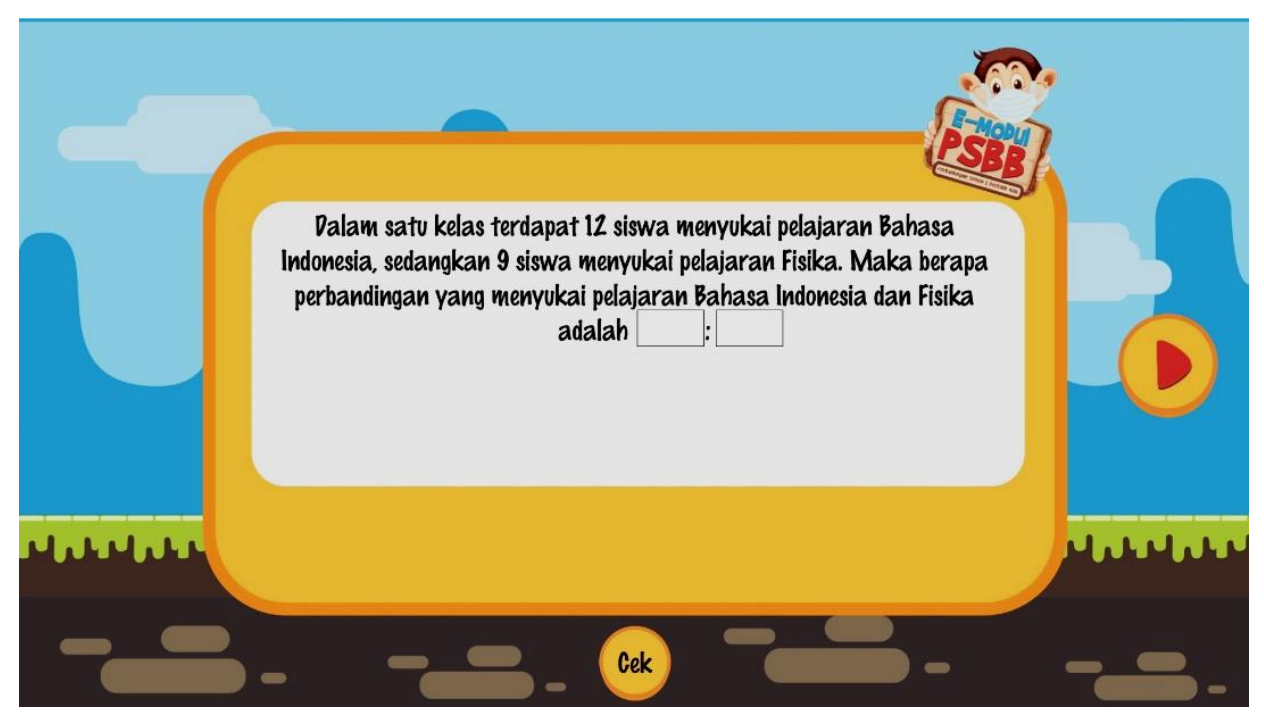

Gambar 5. Soal Evaluasi

Produk yang telah dihasilkan selanjutnya masuk ke tahap validasi ahli media dan ahli materi. Tabel 6 menampilkan hasil uji kevalidan dan Tabel 7 menampilkan hasil kepraktisan media.

Tabel 6. Hasil Uji Kevalidan Media dan Materi

\begin{tabular}{|c|c|c|}
\hline Aspek Penilaian & $(\boldsymbol{\%})$ & Kategori \\
\hline Kesesuaian dengan tujuan & $83 \%$ & Valid \\
\hline Kesesuaian dengan pembelajaran & $78 \%$ & Cukup Valid \\
\hline Praktis, luwes, bertahan, dan cost & $85 \%$ & Valid \\
\hline Penggunaan/ access & $77 \%$ & Cukup Valid \\
\hline Kesesuaian pengelompokan sasarn & $84 \%$ & Valid \\
\hline Mutu teknis/ teknologi & $82 \%$ & Valid \\
\hline Novelty & $80 \%$ & Valid \\
\hline Rata-Rata & $81 \%$ & Valid \\
\hline
\end{tabular}

Hasil rata-rata dari uji kevalidan media dan materi pada Tabel 6 menunjukkan persentase sebesar 
Pengembangan E-Modul Berbasis Aplikasi Android pada Materi Perbandingan Berbalik Nilai, Ilham Kartiko, Helti Lygia Mampouw

$81 \%$ yang termasuk dalam kategori valid. Dari hasil tersebut dapat disimpulkan bahwa e-modul PSBB valid dari segi media dan materi untuk digunakan.

Tabel 7. Hasil Uji Kepraktisan Media

\begin{tabular}{|c|c|c|}
\hline Aspek Penilaian & $(\boldsymbol{\%})$ & Kategori \\
\hline Kesesuaian dengan tujuan & $100 \%$ & Sangat Praktis \\
\hline Penggunaan media & $80 \%$ & Praktis \\
\hline Perawatan dan penyimpanan & $87 \%$ & Praktis \\
\hline Rata-rata & $86 \%$ & Praktis \\
\hline
\end{tabular}

Hasil rata-rata dari uji keprakisan media pada Tabel 7 menunjukkan persentase sebesar $86 \%$ yang termasuk dalam kategori praktis. Dari hasil tersebut dapat disimpulkan bahwa e-modul PSBB praktis untuk digunakan.

Terdapat beberapa saran dan perbaikan dari validator sebagai berikut: (a) penulisan jawaban Mario tidak bisa padahal kata mario bisa namun tidak sesuai pilihan jawaban; (b) ada berat badan orang dewasa tidak kontekstual; (c) setekah ditengah tidak bisa keluar langsung dan jika di klik sebelumnya maka yang sudah dikerjakan menjadi terkunci; (d) teks KD di scrolltext paling bawah terpotong tulisannya; (e) Pada halaman (pengantar) perbandingan saat ini disajikan langsung poin-poin, belum jelas itu definisi perbandingan atau tujuan belajar perbandingan, perlu diberikan pengantar/kalimat awal/sub judul yang jelas.

\section{Tahap Implementasi}

E-modul PSBB diujicobakan kepada siswa SMP Negeri 6 Salatiga kelas VII A-C. Tabel 8 memuat informasi partisipasi siswa pada e-modul PSBB.

Tabel 8. Rincian Jumlah Responden

\begin{tabular}{|c|c|c|c|}
\hline Kelas & Jumlah Siswa & Jumlah Respon siswa & Presentase Respon Siswa \\
\hline Kelas VII A & 32 & 17 & $53 \%$ \\
\hline Kelas VII B & 32 & 10 & $31 \%$ \\
\hline Kelas VII C & 28 & 8 & $29 \%$ \\
\hline Total & 92 & 35 & $38 \%$ \\
\hline
\end{tabular}

Setelah siswa mengamati pembelajaran melalui e-modul PSBB, siswa mengerjakan soal pada LKS dan mengisi penilaian atas kepraktisan e-modul PSBB menggunakan google formulir. Hasil uji keefektifan dapat dilihat pada Tabel 9.

Tabel 9. Hasil Uji Keefektifan Media

\begin{tabular}{|c|c|c|}
\hline Subjek & Ketuntasan (\%) & Kategori \\
\hline Kelas VII A & $88 \%$ & Sangat Efektif \\
\hline Kelas VII B & $80 \%$ & Efektif \\
\hline Kelas VII C & $88 \%$ & Sangat Efektif \\
\hline Rata-rata & $85 \%$ & Sangat Efektif \\
\hline
\end{tabular}

Hasil rata-rata dari uji keefektifan media pada Tabel 9 menunjukan persentase sebesar $85 \%$ yang termasuk dalam kategori sangat efektif. 
Keefektifan e-modul PSBB dapat dilihat juga dari hasil penilaian respon siswa. Hasil penilaian respon siswa dapat dilihat pada Tabel 10.

Tabel 10. Hasil Penilaian Respon Siswa

\begin{tabular}{|c|c|c|}
\hline Pernyataan & $\mathbf{( \% )}$ & Kategori \\
\hline Materi dalam media ini mudah dipahami & $77 \%$ & Baik \\
\hline Media ini dapat saya gunakan dengan mudah & $78 \%$ & Baik \\
\hline $\begin{array}{c}\text { Media ini asyik dan menantang untuk } \\
\text { digunakan }\end{array}$ & $73 \%$ & Baik \\
\hline $\begin{array}{c}\text { Media ini dapat digunakan untuk bermain } \\
\text { sambal belajar }\end{array}$ & $79 \%$ & Baik \\
\hline $\begin{array}{c}\text { Media ini membantu memahami materi } \\
\text { perbandingan }\end{array}$ & $79 \%$ & Baik \\
\hline Rata-rata & $77 \%$ & Baik \\
\hline
\end{tabular}

Hasil rata-rata dari penilaian siswa pada Tabel 10 menunjukkan persentase sebesar $77 \%$ yang termasuk dalam kategori Baik. Berdasarkan hasil pada uji keefektifan dan penilaian respon siswa dapat disimpulkan bahwa e-modul PSBB efektif untuk digunakan.

\section{Tahap Evaluasi}

Tahap ini bertujuan untuk mengevaluasi e-modul PSBB dan penggunaanya di dalam membantu siswa belajar materi perbandingan. Berdasarkan e-modul PSBB yang valid dengan prosentasi kevalidan $81 \%$. Hasil rata-rata uji kepraktisan yang media memperoleh persentase sebesar $86 \%$ yang termasuk kategori praktis. Hasil rata-rata dari uji keefektifan media berdasarkan tingkat ketuntasan siswa menunjukan ratarata persentase sebesar 85\% yang termasuk dalam kategori sangat efektif dan hasil penilaian respons siswa dengan rata-rata persentase sebesar $77 \%$ yang termasuk dalam kategori baik, sehingga dari hasil tersebut dapat disimpulkan bahwa e-modul PSBB efektif untuk digunakan.

\section{Diskusi}

Hasil penelitian menunjukkan bahwa e-modul PSBB yang dikembangkan menggunakan model pengembangan ADDIE adalah valid dari segi media maupun materi, praktis berdasarkan uji kepraktisan media, dan efektif dilihat dari hasil belajar menggunakan media. E-modul PSBB yang valid, praktis dan efektif juga sejalan dengan pengembangan media e-modul berbasis learning content development system pada materi pola bilangan oleh Ula \& Fadila (2018), e-modul berbasis problem based learning pada materi bilangan bulat oleh Hidayatulloh (2016) dan e-modul berbasis android pada materi lingkaran oleh Wahyudi (2019). Kelebihan dari e-modul PSBB adalah membantu pembelajaran perbandingan senilai dan berbalik nilai pada masa pandemi Covid-19, dapat diunduh dan disimpan di dalam smartphone berbasis android minimal versi 7, dapat dijalankan berulang-ulang pada smartphone secara offline dan dapat digunakan siswa SMP di mana saja dan kapan saja. 
Pengembangan E-Modul Berbasis Aplikasi Android pada Materi Perbandingan Berbalik Nilai, Ilham Kartiko, Helti Lygia

\section{KESIMPULAN}

Berdasarkan hasil penelitian yang dilakukan menggunakan model pengembangan ADDIE di dapat sebuah produk berupa e-modul PSBB dengan persentase rata-rata kevalidan sebesar $81 \%$ yang termasuk dalam kategori valid dan praktis digunakan dengan persentase rata-rata kepraktisan sebesar $86 \%$ yang termasuk dalam kategori praktis. Hasil rata-rata dari uji keefektifan media berdasarkan tingkat ketuntasan siswa menunjukan rata-rata persentase sebesar $85 \%$ yang termasuk dalam kategori sangat efektif dan hasil penilaian respons siswa dengan rata-rata persentase sebesar $77 \%$ yang termasuk dalam kategori baik, sehingga dari hasil tersebut dapat disimpulkan bahwa e-modul PSBB efektif untuk digunakan.

Pengembangan e-modul sangat relevan dengan era Revolusi Industri 4.0 terutama pada saat pembelajaran tatap muka agak terkendala. Oleh karena itu diharapkan media pembelajaran jenis e-modul dapat dikembangkan untuk materi matematika lainnya. Penggunaan LKS perlu diadakan dan direncanakan dengan baik sehingga dapat berfungsi sebagai alat kontrol kemajuan belajar siswa sekaligus sebagai alat evaluasi terhadap indikator pencapaian kompetensi oleh siswa.

\section{UCAPAN TERIMA KASIH}

Peneliti berterimakasih kepada Rektor Universitas Kristen Satya Wacana, Dekan Fakultas Keguruan dan Ilmu Pendidikan Universitas Kristen Satya Wacana, Kaprogdi Pendidikan Matematika FKIP UKSW, Dosen Pembimbing, Guru SMP, Siswa SMP, dan seluruh pihak yang telah membantu dalam pelaksanaan kegiatan ini, sehingga terlaksana dengan baik.

\section{REFERENSI}

Andika, Y. (2017). PENGEMBANGAN E-MODULE INTERAKTIF BERBASIS PROBLEM BASED LEARNING PADA MATERI KUBUS DAN BALOK KELAS VIII SMP. JPM : Jurnal Pendidikan Matematika, 3, 31-36. http://riset.unisma.ac.id/index.php/jpm/article/view/2608

Aswardi, Mukhaiyar, R., Elfizon, \& Nellitawati. (2019). Pengembangan Trainer Programable Logic Gontroller Sebagai Media Pembelajaran. Jurnal Teknik Elektro Dan Vokasional, V(1), 51-56.

Dahar, R. (2016). Teori-Teori Belajar \& Pembelajaran. Bandung: Gelora Aksara Pratama

Data Pamer UN (Ujian Nasional) Tahun 2019 diakses melalui https://hasilun.puspendik.kemdikbud.go.id

Hamidah, D., Putri, R. I. I., \& Somakim, S. (2018). Eksplorasi Pemahaman Siswa pada Materi Perbandingan Senilai Menggunakan Konteks Cerita di SMP. Jurnal Riset Pendidikan Dan Inovasi Pembelajaran Matematika (JRPIPM), 1(1), 1. https://doi.org/10.26740/jrpipm.v1n1.p1-10

Hidayatullah, M. S. (2016). Pengembangan Media Pembelajaran Berbasis Flip Book Maker Pada Mata Pelajaran Elektronika Dasar Di SMK Negeri 1 Sampang. Pendidikan Teknik Elektro, 5(1), 83-88. https://jurnalmahasiswa.unesa.ac.id/index.php/jurnal-pendidikan-teknik-elektro/article/view/13674

Hidayatulloh, M. S. (2003). Pengembangan E- Modul Matematika Berbasis Problem Based Learning Berbantuan Geogebra. Pendidikan Matematika FPMIPA Universitas PGRI Semarang, 1(2), 24-31.

Ishana, M. (2014). Untuk Materi Perbandingan Pada Pembelajaran Matematika Siswa Kelas Vii Smpn 3 
Sutera Kabupaten Pesisir Selatan Mega Ishana Sekolah Tinggi Keguruan Dan Ilmu Pendidikan (Stkip) Pgri Sumatera Barat Padang.

Permendikbud Nomor 37 Tahun 2018 Tentang Kompetensi Dasar Materi Perbandingan.

Raharjanti, M., Nusantara, T., \& Mulyati, S. (2016). Kesalahan Siswa Dalam Menyelesaikan Permasalahan Perbandingan Senilai dan Berbalik Nilai. Konferensi Nasional Penelitian Matematika Dan $\begin{array}{llll}\text { Pembelajarannya (KNPMP } & \text { March, }\end{array}$ https://publikasiilmiah.ums.ac.id/bitstream/handle/11617/6971/33_130_Makalah Rev Meliyana Raharjanti.pdf?sequence=1\&isAllowed=y

Sugiono. (2018). Metodologi Penelitian Kuantitatif, Kualitatif, dan R\&D. Bandung: Alfabeta.

Tiffani, H. (2015). Profil Proses Berpikir Sisiwa SMP dalam Menyelesaikan Soal Perbandingan Berdasarkan Gaya Belajar dan Gaya Kognitif. Universitas Muhammadiyah Surakarta.

Ula, I. R., \& Fadila, A. (2018). Pengembangan E-Modul Berbasis Learning Content Development System Pokok Bahasan Pola Bilangan SMP. Desimal: Jurnal Matematika, 1(2), 201. https://doi.org/10.24042/djm.v1i2.2563

Wahyudi, D. (2019). PENGEMBANGAN E-MODUL DALAM PEMBELAJARAN MATEMATIKA SMA BERBASIS ANDROID. GAUSS: Jurnal Pendidikan Matematika, 02(02), 1-10. 